J. Reprod. Fertil. (1965) 10, 185-188

\title{
GLUTAMIC-OXALOACETIC TRANSAMINASE IN HUMAN SEMEN AND REPRODUCTIVE ORGANS
}

\author{
CHARLES A. JOËL AND MALA HERZBERG \\ Institute for Research and Treatment of Fertility Disturbances, and \\ Biochemical Laboratories of the Municipal Hospitals, \\ Tel-Aviv-Yafo, Israel
}

(Received 10th November 1964, revised 5th April 1965)

\begin{abstract}
Summary. Determinations were made of glutamic-oxaloacetic transaminase activity in 135 ejaculates, ten testicular biopsy specimens, and post-mortem material consisting of testes, epididymides, seminal ducts, prostate glands and seminal vesicles. Transaminase levels in semen appeared to be directly related to sperm concentration. Lowest values were observed in azoospermic and aspermic semen. The various organs which compose the male reproductive tract did not differ much in transaminase activity.
\end{abstract}

\section{INTRODUCTION}

So far few reports have been published on the level of transaminase activity in human ejaculates and male reproductive organs (Povoa \& Villela, 1960; Gregoire, Rakoff \& Word, 1961; Searcy, Craig \& Bergquist, 1962; Barron \& Huggins, 1946; Awapara, 1952; Mann, 1954). We therefore made it our task to perform systematic transaminase determinations in a large number of normal and pathological ejaculates, with a view to finding out whether there exists a relation between the level of transaminase activity and sperm concentration. Furthermore, by an investigation of the testis, epididymis, seminal duct, seminal vesicle and prostate, we set out to determine which of these organs is richest in transaminase.

\section{MATERIAL AND METHODS}

Transaminase determinations were made in (i) 135 ejaculates of men aged 23 to 54 years, (ii) ten testicular biopsy specimens and (iii) post-mortem material from six men, comprising testes, epididymides, prostate glands, seminal ducts and seminal vesicles (the latter from three men only); from five men, both semen and testicular biopsy specimens were available.

The evaluation of semen quality was based on the criteria listed in Table 1 .

Glutamic-oxaloacetic transaminase (GOT, glutamate-aspartate transaminase) determinations were made by the method of Reitman \& Frankel (1957): $0.1 \mathrm{ml}$ ejaculated semen and $0.5 \mathrm{ml}$ substrate were placed in two test-tubes; to one, which served as blank, $0.5 \mathrm{ml}$ dinitrophenylhydrazine solution was added immediately, and to the other after $1 \mathrm{hr}$ incubation at $38^{\circ} \mathrm{C}$. Twenty minutes 
later $5 \mathrm{ml} 0.5 \mathrm{~N}-\mathrm{NaOH}$ solution were added to both test-tubes, and after another $10 \mathrm{~min}$ the colour intensity was determined in a Klett colorimeter using a green filter $(540 \mathrm{~m} \mu)$.

In biopsy specimens and post-mortem material the GoT determinations were carried out after grinding the tissue with sand in fifty parts normal saline, followed by centrifugation. The results were expressed in enzyme units $/ 1 \mathrm{ml}$ seminal plasma or $1 \mathrm{~g}$ fresh tissue.

TABLE 1

EVALUATION OF NORMAL AND PATHOLOGICAL SEMEN

\begin{tabular}{l|c|c|c|c}
\hline & $\begin{array}{c}\text { Sperm. conc. } \\
\left(10^{6} / \mathrm{ml}\right)\end{array}$ & $\begin{array}{c}\text { Sperm. motility } \\
\text { at } \frac{1}{2}-2 \text { hr after } \\
\text { ejaculation }(\%)\end{array}$ & $\begin{array}{c}\text { Normal } \\
\text { sperm. }(\%)\end{array}$ & $\begin{array}{c}\text { Immature } \\
\text { sperm. forms }(\%)\end{array}$ \\
\hline Normospermia & 60 & 80 & 80 to 85 & $0 \cdot 5$ to 2 \\
Hypozoospermia & 60 to 30 & 80 to 60 & 80 to 50 & 2 to 5 \\
Oligozoospermia & 30 to 1 & 60 to 30 & 50 to 20 & 10 to 40 \\
$\begin{array}{l}\text { Azoospermia } \\
\text { Aspermia }\end{array}$ & 0 & 0 & 0 & 100 \\
& 0 & 0 & 0 & 0 \\
\hline
\end{tabular}

TABLE 2

GLUTAMIC-OXALOACETIC TRANSAMINASE ACTIVITY IN SEMEN (UNITS/ML)

\begin{tabular}{l|c|c|c}
\hline \multirow{2}{*}{ Semen } & $\begin{array}{c}\text { No. of } \\
\text { specimens }\end{array}$ & \multicolumn{2}{|c}{ Transaminase activily } \\
\cline { 2 - 3 } & 40 & Range & Average \\
\hline Normospermia & 12 & 35 to 270 & $122 \cdot 6 \pm 59 \cdot 7$ \\
Hypozoospermia & 62 & 5 to 200 & $90 \cdot 5 \pm 49 \cdot 1$ \\
Oligozoospermia & 19 & 5 to 38 & $64 \cdot 5 \pm 52 \cdot 4$ \\
Aspermia and azoospermia & & $18 \cdot 6 \pm 9 \cdot 1$ \\
\hline
\end{tabular}

\section{RESULTS}

The data provided in Table 2, which include ranges of activity, averages and standard deviations for transaminase in human semen, indicate that there exists a direct relationship between sperm concentration and enzyme activity. The highest transaminase values were observed in normal semen (normospermia) as well as in those cases of hypozoospermia which were still near the limits of normality. The lowest transaminase values have been recorded in cases of azoospermia and aspermia, while in oligozoospermia the activity was intermediate.

From Table 3, which affords a direct comparison, it appears that there is no definite relationship between the enzyme activity in semen and in testes, either normal or atrophied to such an extent that the semeniferous tubules contained only Sertoli cells (Grade IV, as defined by Joël, 1953).

Further, Table 3 shows that, while transaminase values in oligospermic and aspermic ejaculates were always low, no marked difference existed between the various testicular biopsy specimens, irrespective of the state of spermatogenesis in the testes. 
Table 4 shows the transaminase values in testis, epididymis, ductus deferens, seminal vesicle and prostate gland. There does not appear to be much difference in transaminase activity between the different organs, but the highest value of all $(42,500$ units/g tissue) was recorded in a prostate gland.

TABLE 3

GLUTAMIC-OXALOACETIC TRANSAMINASE ACTIVITY IN SEMEN (UNITS/ML) AND IN TESTICULAR BIOPSY SPECIMENS (UNITS/G WET WT)

\begin{tabular}{|c|c|c|c|c|}
\hline \multirow{2}{*}{ No. } & \multirow{2}{*}{ Semen } & \multicolumn{2}{|c|}{ Transaminase activity } & \multirow{2}{*}{ State of testis } \\
\hline & & In semen & In testis & \\
\hline $\begin{array}{r}1 \\
2 \\
3 \\
4 \\
5 \\
6 \\
7 \\
8 \\
9 \\
10\end{array}$ & $\begin{array}{l}\text { Oligozoospermia } \\
\text { Aspermia } \\
\text { Aspermia } \\
\text { Aspermia } \\
\text { Aspermia } \\
\text { Aspermia } \\
\text { Aspermia } \\
\text { Aspermia } \\
\text { Oligozoospermia } \\
\text { Aspermia }\end{array}$ & $\begin{array}{l}10 \\
26 \\
5 \\
42 \\
20 \\
- \\
- \\
-\end{array}$ & $\begin{array}{rr} & 28 \cdot 000 \\
& 26 \cdot 000 \\
& 30 \cdot 250 \\
& 34 \cdot 500 \\
& 18 \cdot 750 \\
& 4 \cdot 500 \\
& 15 \cdot 000 \\
& 46 \cdot 000 \\
\text { R } & 30 \cdot 000 \\
\text { L } & 28 \cdot 000 \\
\text { R } & 42 \cdot 500 \\
\mathbf{L} & 43 \cdot 500\end{array}$ & $\begin{array}{l}\text { Atrophy I-II } \\
\text { Atrophy II-III } \\
\text { Atrophy IV } \\
\text { Normal } \\
\text { Atrophy II-III } \\
\text { Atrophy II-III } \\
\text { Normal } \\
\text { Normal } \\
\text { Atrophy I-IV } \\
\text { Normal }\end{array}$ \\
\hline
\end{tabular}

Testicular tissue was obtained in individuals Nos. 1 to 8 from the right gonad, in Nos. 9 and 10 from both gonads (right, $R$, and left, L). The amount of testicular tissue available was usually 16 to $55 \mathrm{mg}$, except in No. 6 where it was only $11 \mathrm{mg}$ wet wt. The figures I to IV denote the four grades of testicular atrophy as defined by Joël (1953).

TABLE 4

GLUTAMIC-OXALOACETIC TRANSAMINASE ACTIVITY (UNITS/G WET WT) IN TESTES AND MALE ACCESSORY ORGANS

\begin{tabular}{c|c|c|c|c|c|c|c|c}
\hline & \multicolumn{2}{|c|}{ Testis } & \multicolumn{2}{c|}{ Epididymis } & \multicolumn{2}{c|}{ Ductus deferens } & Seminal & Prostate \\
No. & \multicolumn{2}{|c|}{ Right } & Left & Right & Left & Right & Left & $\begin{array}{c}\text { Sesicle } \\
\text { vland }\end{array}$ \\
\hline & 20,500 & 18,000 & 32,000 & - & 7,000 & 4,250 & - & 19,500 \\
1 & 24,000 & 26,250 & 18,500 & 9,000 & 12,000 & 9,000 & - & 16,250 \\
3 & 22,500 & 27,500 & 35,000 & 16,250 & - & - & 10,000 \\
4 & 20,000 & 16,500 & 16,500 & 13,000 & 20,000 & 7,000 & - & 42,500 \\
5 & 14,000 & 19,500 & 12,000 & 12,500 & 9,500 & - & - & 6,500 \\
6 & 17,000 & 11,600 & 19,000 & 15,400 & 6,400 & 7,300 & - & 17,400 \\
7 & - & - & - & - & - & - & 14,200 & - \\
9 & - & - & - & - & - & - & 6,200 & - \\
\hline
\end{tabular}

\section{DISCUSSION}

The investigations conducted so far have not elucidated the role played by transaminase in the male genital tract. There does appear to exist a direct relationship between sperm concentration and transaminase activity in human semen. Nevertheless, it is clear from our analyses that the testes cannot be regarded as the sole source of transaminase. It would seem that the prostate, owing to its relatively large size, makes a particularly important contribution towards the total activity of the human ejaculate. 


\section{ACKNOWLEDGMENT}

We wish to thank Professor J. Fisher for his interest, help and advice.

\section{REFERENCES}

Awapara, J. (1952) Distribution of transaminase in rat organs. F. biol. Chem. 194, 497.

Barron, G. E. S. \& Huggrns, C. (1946) The metabolism of the prostate: Transamination and citric acid. 7. Urol. 55, 385.

GREGoIRE, A. T., RAKoff, A. E. \& WORD, K. (1961) Glutamic-oxaloacetic transaminase in semen of human, bull and rabbit seminal plasma. Int. F. Fertil. 6, 1.

JoËL, C. A. (1953) Studien am menschlichen Sperma. Benno Schwabe, Basel.

Mann, T. (1954) Biochemistry of semen. Methuen, London.

PovoA, H., Jr. \& Villela, G. C. (1960) Transaminase in seminal plasma of man. Experientia, 16, 199.

RerTMan, S. \& Frankel, S. (1957) Colorimetric method for determination of serum glutamic-oxaloacetic and glutamic pyruvic transaminases. Amer. F. clin. Path. 28, 56.

Searcy, R. L., Craig, R. G. \& Bergquist, L. M. (1962) Levels of transaminase in human seminal plasma. Lancet, $\mathbf{i}, 1413$. 